\title{
Transformations économiques dans la vie des pêcheurs de la côte occidentale du Venezuela
}

\section{Maria-Matilde Suarez et Jorge Carillo}

\section{(2) OpenEdition \\ Journals}

Édition électronique

URL : https://journals.openedition.org/tc/826

DOI : $10.4000 /$ tc. 826

ISSN : 1952-420X

Éditeur

Éditions de l'EHESS

\section{Édition imprimée}

Date de publication : 1 octobre 1988

ISSN : 0248-6016

\section{Référence électronique}

Maria-Matilde Suarez et Jorge Carillo, «Transformations économiques dans la vie des pêcheurs de la côte occidentale du Venezuela », Techniques \& Culture [En ligne], 11 | 1988, mis en ligne le 16 janvier 2006, consulté le 29 septembre 2022. URL : http://journals.openedition.org/tc/826 ; DOI : https:// doi.org/10.4000/tc.826

Ce document a été généré automatiquement le 29 septembre 2022.

Tous droits réservés 


\section{Transformations économiques dans} la vie des pêcheurs de la côte occidentale du Venezuela

Maria-Matilde Suarez et Jorge Carillo 